\title{
7
}

\section{PUTTING ON A SHOW AND ELECTORAL FORTUNES IN TAIWAN'S MULTI-PARTY ELECTIONS}

\author{
Dafydd Fell
}

\section{Introduction: Theatre Politics and Electoral Fortunes in Taiwan}

Given the high symbolic content of Taiwanese campaigns, analysing elections in Taiwan through the lens of theatre politics is particularly appropriate. The value of examining Taiwanese politics in theatrical terms, defined by Joseph Esherick and Jeffrey Wasserstrom (1990: 839) as 'symbolic-laden performances whose efficacy lies largely in their power to move specific audiences,' is clearly perceived by the island's election correspondents. Journalistic commentaries on campaigns abound with theatrical terms. Candidates' skills at putting on a show (zuoxiu) or performing are compared by newspaper columnists, who view this as a key requirement for a successful election candidate (Chen Chao-ju 1997). The word $x i u$ is a transliteration of the English 'show' and the usage of the phrase zuoxiu to denote putting on a show appears unique to Taiwan. ${ }^{1}$ The scope of the term is very broad, and can include candidates' ability to make speeches, take part in electoral stunts, attend funerals and weddings, make good TV election ads, hold moving election rallies, debate on politics talk shows, and even fight.

In contrast to journalistic accounts of politicians' shows in Taiwan's elections, political scientists working on Taiwan are less comfortable with these concepts and thus have given little attention to symbolic campaigning. Research on Taiwanese electoral politics has tended to focus on either the clientelistic campaigning, known as the 'organizational battle' (zuzhi zhan) (Rigger 1999: 41-54; Wang Chin-shou 1997: 3-62), or the 'propaganda battle' (wenxuan zhan). The propaganda research has concentrated on changing political communication techniques and electoral debate over political issues, particularly national identity (Cheng Tzu-long 1995; Fell 2002: 31-60; Lin Tsong-jyi 2002: 123-43; Cheng and Hsu 1996: 137-73). 
This chapter examines the relationship between candidates' ability to put on a show on the electoral stage and electoral results in Taiwan. Although symbolic performances are one among a myriad of factors influencing voting behaviour and the skill of putting on a show does not guarantee electoral victory, it does give a significant advantage. In fact, media liberalization in conjunction with the decline in effectiveness of clientelistic electioneering and ruling party political rituals have meant that the influence of symbolic campaigning on election results has risen in recent years. It is argued that the electoral success and failure of Taiwan's parties and candidates has increasingly been tied to their ability to adapt to the demands of a rapidly changing media stage and electoral audience. The content and style of political shows can rapidly become outdated. Therefore, increasingly, those politicians able to design their campaign performances to match audience tastes have tended to win elections, while those that have failed to keep up with performance fads have faded from the political scene.

After 40 years of Martial Law, Taiwan held its first full democratic election that had the potential to change the balance of power in 1991. The sweeping away of restrictions on opposition parties and freedom of speech, and the liberalization of Taiwan's media created a radically new electoral environment, in which politicians would either sink or swim. This was a transformation as great as the one facing actors adjusting from the stage to the big screen or from silent to talking motion pictures. Martial Law-era politicians now faced a highly demanding electoral audience and an ever-changing media stage to perform on. The first democratic elections were an experiment not only in the policies but also the symbolic campaigning that voters would accept.

Following this brief introduction, Section two outlines the limited scope for theatre politics, and dominance of the ruling Kuomintang's (KMT) political rituals and organizational battle in Taiwan's Martial Law era (1949-87). Next Sections three to five examine how politicians and parties adjusted their performances in the period of democratic transition, the first five years of full multi-party elections, and since the advent of cable news channels. The link between anticipation of audience tastes for political shows and electoral results is outlined in a number of case studies. Finally the conclusion reviews the main findings of the paper and their implications.

\section{Theatre Politics and Ruling Party Rituals in Martial-Law Taiwan}

Taiwan was under Martial Law from 1949 until 1987. Since the Republic of China claimed to be the sole legitimate government of all China, it justified postponing full national elections until it could recover the Chinese Mainland. However, throughout this period regular local elections up to the level of the Provincial Assembly were held. Although opposition parties were not permitted, independent non-KMT candidates were allowed to stand, and competition between the ruling KMT's rival factions ensured these local elections were intensely 
fought. Moreover, a limited number of seats in the two national parliaments were opened up for direct election after 1969.

During Martial Law, the KMT was able to dominate the electoral process and leave little scope for spontaneous theatre politics. Instead, the organizational battle tended to determine electoral outcomes and electoral communication in the media was saturated with ruling party rituals. While the propaganda battle involves open public and media campaigning, the organizational battle is the private face of the campaign. This includes the work of the vote brokers, mobilization of KMT support groups, vote allocation and division of constituencies into responsibility zones. Campaigning restrictions ensured that during the Martial Law era the organizational battle had a far greater impact on electoral success or failure (Tien 1989: 179-81). Election results were often determined months before voting day. Since only the KMT had the financial and organizational resources to co-ordinate election campaigns, getting nominated as a party candidate virtually guaranteed victory. For instance, between 1954 and 1989, an average of 85.86 per cent of KMT Provincial Assembly candidates won election (Chen Ming-tong 1996: 174-93).

Both the print and electronic media were dominated by the ruling KMT, making it hard for opposition politicians to gain media exposure or propagate alternative political ideals. Instead, the media was awash with political ritual, defined by Esherick and Wasserstrom (1990: 844) as 'traditionally prescribed cultural performances that serve as models of and models for what people believe.' The ruling party's political rituals were highly rule-governed performances designed to legitimize the KMT's authority and ideology. The state ceremonies such as National Day and Retrocession Day were broadcast live on television, and presided over solely by KMT politicians. ${ }^{2}$ Similarly, at election time the focus of the television and radio news was the activities of KMT government officials and its election candidates, invariably playing the role of the competent but benevolent ruler. By contrast, any news items regarding the opposition would invariably show them in a negative light. A master of these ruling party rituals was President Chiang Ching-kuo. During the 1980s he was able to caste aside the sinister image created by his long involvement in the secret services during the height of political persecution (Wang 1999: 320-39). In its place Chiang exploited countless photo opportunities showing him looking relaxed with ordinary people, thus successfully cultivating the image of a down-to-earth man of the people.

Numerous restrictions on the content and forms of campaign activities limited the impact of the propaganda battle on election results. Only short campaign periods were permitted, and both large candidate rallies and campaign advertising were banned. Moreover, if candidates touched upon politically taboo subjects such as criticizing the president, advocating independence or communism for Taiwan, they were liable to receive long jail sentences (Tien 1989: 162-94). For instance, in 1968 the journalist Po Yang received a ten-year jail sentence for a 
newspaper cartoon poking fun at President Chiang Kai-shek (Chao and Myers 1998: 5).

Despite the limitations on Martial Law campaigns, they were colourful and noisy events, with a festival atmosphere. To make themselves known to floating voters, candidates would place campaign flags reminiscent of ancient Chinese battle banners throughout their constituency. These showed the candidate's name and sometimes a small slogan or badge. Every street and paddy field was lined with these flags, often creating traffic chaos when they covered up traffic lights. While firecrackers were set off at Chinese New Year to scare off evil spirits, election candidates stood on open campaign vehicles and set off firecrackers to attract attention. Similarly, wealthy candidates competed to see who could provide constituents with the largest scale election banquet. For beggars, election campaigns were far more attractive than traditional Chinese festivals due to the availability of weeks of free meals. In addition, personal contact with voters was seen as effective, thus candidates had to attend endless weddings and funerals, and shake hands at street markets.

During the last decade of Martial Law there was a limited loosening of campaign restrictions, and a semi-organized opposition movement began to coalesce around a group of democracy activists. The opposition movement frequently tested the KMT's limits of toleration in both its issue demands and campaign methods. Dissidents were able to make use of the relative freedom of expression during the short campaign periods, which became known as 'democratic holidays' (minzhu jiaqi). The formally dull Central Election Commission-run policy forums were reinvigorated, as dissidents used them as a stage to get their message across and display their speech-making skills. According to the veteran dissident politician Chu Kao-cheng, these policy forums were his most effective campaign method under Martial Law (Interview with Chu, 2001).

However, the KMT was still prepared to crack down if the opposition movement grew too strong. When in 1979 the opposition attempted to organize a large-scale human rights march, the KMT rounded up almost the entire opposition leadership and put them on military trial (Kaplan 1981). This was known as the Kaohsiung or Formosa Incident, and the defendants received sentences of between 12 years and life. In a sign that Taiwan's political climate was changing, ruling party rituals such as these show trials no longer had their desired effects. While the February 28 Incident massacres of 1947 and White Terror of the 1950s and 1960s had cowed Taiwanese into submission, the 1980 show trials seriously backfired with the domestic audience. ${ }^{3}$ The trials discredited the KMT and actually rejuvenated and strengthened the opposition movement. They not only made the defendants into heroes, but they also created a new generation of opposition stars; these were the defence lawyers and the wives of the imprisoned defendants. Throughout the 1980s, the opposition exploited the sympathy vote by making these politicians the focal point of the election activities. 


\section{Theatre Politics during the Democratic Transition: 1987-91}

After almost 40 years Martial Law was finally ended in July 1987, sweeping away many of the pre-existing campaign restrictions. However, though opposition parties were allowed, national elections were still supplementary, with less than a third of seats open for direct election. Opposition politicians still struggled to reach their audience, as the electronic media remained dominated by the KMT. The ruling party stayed reliant on its organizational battle and political rituals to win elections. The newly formed Democratic Progressive Party (DPP) lacked both the financial clout and organizational strengths to compete with the KMT's organizational battle. Instead it had to rely on the propaganda battle. The principal stages for opposition politicians to perform were street marches, parliaments, campaign rallies and the realm of stunt politics.

While previously only state-sanctioned ritualistic or non-political marches had been permitted, the end of Martial Law saw a surge in the number of marches and demonstrations. This was a critical tool for the DPP in spreading its agenda, and opposition figures needed to be skilled at organizing and performing at such events. During the DPP's first five years, large demonstrations were held calling for full national elections, direct presidential elections, freedom of speech and application to rejoin the United Nations. The novelty of street demonstrations was revealed in the 1989 Taiwanese rap song titled 'Song of Madness' (zhuakuang $g e$ ). This described the bewilderment of a country bumpkin visiting Taipei and seeing his first-ever demonstration. In confusion he asks a policeman: 'Are they preparing to counter attack the Chinese Mainland?' Although there were some isolated violent incidents in these demonstrations, most DPP politicians were at pains to avoid violence in the streets, as they were aware of voters' fears of social disorder.

The second forum for opposition politicians was the political rallies that became exceedingly common and popular in this period. As political scientist Tien Hung-mao (1989: 183) recalled, 'it is not unusual to have over twenty thousand people attend, compared to several hundred that show up at rallies for KMT candidates.' Opposition party politicians had to learn to satisfy the new and demanding audience by attacking the KMT and making radical and controversial political demands. They were also expected to make their passionate speeches in the formally suppressed Taiwanese language, rather than the national language, Mandarin. ${ }^{4}$ This meant that numerous moderate dissidents such as Kang Ning-hsiang or Mainlanders unable to speak Taiwanese fell from favour among opposition supporters. ${ }^{5}$ KMT candidates also organized election rallies and banquets during this period, however, these contrasted sharply with those run by the opposition party. These tended to have little policy content and were more like variety shows, being hosted by TV stars and featuring pop stars and scantily dressed singers.

Even though the opposition members only accounted for a small proportion 
of parliamentarians, the quality of their speeches and performances made some of them into political stars. Especially renowned were the DPP Legislators Chen Shui-bian, Hsieh Chang-ting and Lin Cheng-chieh, who gained the nickname 'The Three Musketeers' (Shen and Wu 1996). The newly liberalized print media recorded these politicians' campaign and parliamentary speeches in their politics columns. A number of DPP politicians also used violence in parliament to gain publicity and protest against the slow pace of political reforms. Particularly famous incidents were the man known as Taiwan's Rambo, Chu Kao-cheng's attacks on the Legislative Yuan speaker, and Huang Chao-hui overturning tables at the President's banquet in the March 1990 National Assembly (Chao and Myers 1998: 186-7, 277). The KMT regularly used the DPP's theatrical performances in its propaganda to discredit it as radical and violent (KMT advertisement 1994). ${ }^{6}$ However, in the late 1980 s, the only way for DPP figures to get television exposure was by using violence, and such actions gained politicians cult status among the opposition's hardcore supporters.

In this period politicians from all parties began to use stunt politics to attract voter attention. One especially noteworthy event was when DPP candidate Lu Hsiu-yi promised his rally in November 1989 would feature the head of the World United Formosans for Independence Kuo Pei-hong. Since Kuo was a blacklisted political exile who had been smuggled into Taiwan and was on the run from the police, the rally attracted a huge crowd. ${ }^{7}$ After Kuo had made his speech and given a press conference, the police were ready to arrest him. However, in unison Kuo and the whole audience put on identical black masks and the lights were turned out, allowing Kuo to escape in the confusion (Cheng 1995: 298). This stunt certainly paid dividends for $\mathrm{Lu}$, who was the highest vote-getter in Taipei County that year. Of course not all the stunts paid off electorally. A prime example was the Labour Party candidate and striptease artist Hsu Hsiao-tan. Hsu produced one of the most talked about newspaper ads of the 1989 campaign, which showed a naked Hsu breaking through a KMT flag and the slogan 'the breast resists the fist' (naitou duikang quantou) (Ibid.: 1995: 299). Moreover, Hsu was able to attract large (mostly male) crowds for her campaign performances. However, Hsu failed to win election in 1989, 1992 and 1995.

The new style of political campaigning contributed to the high turnover of parliamentarians during this period, as politicians from both parties that lacked the newly required performing skills failed to win re-election and faded from the political scene. Although some Martial Law-era KMT politicians could still win election using the organization battle, they were less competitive, as many lacked the qualities for democratic campaigns. Not surprisingly the proportion of KMT legislative candidates winning election fell from 96.66 per cent in 1980 to only 63.26 per cent in 1992 (Chen Ming-tong 1996: 189). The DPP's performances of the late 1980 s were remarkably successful. Despite its media disadvantage, it was able to set the political agenda and increase its vote share from 22.17 per 
cent in 1986 to 28.26 per cent in 1989 (Hsieh 2002: 37). In multi-member electoral districts the opposition's star performers were routinely the top votegetters. However, their radical methods meant they faced a bottleneck in growth by the early 1990s as full democratization made direct action and parliamentary violence hard to justify.

\section{Theatre Politics in the first five years of full democratic elections: 1991-96}

The electoral stage changed considerably in the early 1990s, as the pace of democratization increased. The scope of elected offices broadened rapidly, with the first full elections of the National Assembly in 1991, Legislative Yuan in 1992, the Provincial Governor, Taipei and Kaohsiung Mayor in 1994, and the President in $1996 .^{8}$

Although the first television campaign advertisements were broadcast in 1991, these only had a limited impact on election campaigns in the early 1990s. Instead, many opposition figures continued to employ theatrical methods learnt during the 1980s. These included radical demands, some use of violence, the tragic Taiwanese appeals and a refusal to use Mandarin in election activities. The tragic Taiwanese appeal was common in many DPP campaign ads in the early 1990s, and focused on Taiwan's historical tragedies such as the February 28 Incident and how Taiwanese suffered during the Martial Law White Terror period. ${ }^{9}$ In three 1992 DPP TV ads, the wives of opposition politicians told heartrending stories of how their families had suffered political persecution under Martial Law. DPP advertising also appealed to anti-Mainlander sentiment by playing the ethnic card. For instance, another series of 1992 DPP TV ads showed an actor impersonating Mainlander Premier Hau Pei-tsun's numerous verbal gaffes. One of these reminded voters that Hau had once said: 'I love Taiwan, I love the Mainland [China] even more.' In fact it is felt within the DPP that such exclusive symbolic appeals that had long been taboo subjects under Martial Law had been highly effective in increasing support levels during the transition to democracy. As Hau admitted in an interview, 'Of course (those attacks) were related to ethnicity. So I was the last Mainlander Premier' (Interview with Hau, 2001).

The 1991 National Assembly election was a critical election for the DPP. The party made radical Taiwan independence its central election plank, and tried to convince voters with lengthy academic-style newspaper and TV ads. The DPP suffered a humiliating defeat. Its vote share dropped sharply and some of its most extremist candidates such as Lin Cho-shui were defeated. In fact, in interviews, a number of DPP politicians compared this campaign to the British Labour Party's disastrous 1983 campaign. The election led the party to try to change its image and adopt new campaign methods. For the KMT, on the other hand, the conclusion was that organizational battle and the prevalence of its political rituals in the KMT-dominated media would still be enough to win elections, with only limited attention to the propaganda battle. 
Three years later, however, the 1994 Taipei Mayoral elections showed that organizational advantage no longer guaranteed victory and that the ability of politicians to adjust their performances was critical on the new electoral stage. The DPP's candidate, Chen Shui-bian, had been a radical political figure in the 1980s. In 1989 he had released a leaflet with the seditious slogan 'Long Live Taiwan Independence.' ${ }^{10}$ However, by 1994 Chen's campaign team sensed the change in audience tastes, thus were at pains to show his moderation. Chen Shui-bian rejected the old tragic Taiwanese appeals, and instead adopted a youth-orientated style with the slogan 'Happiness, Hope, Chen Shui-bian' (kuaile, xiwang, Chen Shui-bian). In contrast to the serious atmosphere of early DPP rallies, Chen's team used cheerful pop songs at rallies in a bid to appeal beyond traditional opposition supporters to younger and middle-class voters. In fact this new style of campaigning turned out to be remarkably successful among younger voters. In 1993 only 11.1 per cent of the 20-29 age group supported the DPP, making it the age group least likely to vote DPP. However, by 2002 and after less than a decade of youthorientated campaigning 38.8 per cent of the 20-29 age group supported the DPP, making them the age group most likely to vote DPP (Yang 2002: 17).

This election also featured the newly formed New Party (NP). Just as student protestors in Beijing had usurped Hu Yaobang's state funeral in April 1989, the NP attempted to stake claim to the Republic of China's nationalist rituals (Esherick and Wasserstrom 1990: 840). The party held its own more 'orthodox' national ceremonies, such as at the Yang Mingshan Revolutionary Martyrs Shrine. Similarly, its rallies featured national anthem singing, flag waving and condemning both mainstream parties for their lack of patriotism. Such symbolic appeals enabled the NP to attract many disaffected KMT supporters and became a significant electoral force in the mid-1990s.

The 1994 Taipei mayoral contest also featured a new stage for politicians to perform on: Taiwan's first live televised debate. In the event the DPP's Chen Shui-bian was scathing in his criticism of the incumbent KMT mayor, but also attempted to show his own government competence. The NP's Chao Shao-kang gave by far the most theatrical performance, opening with the statement 'Taiwan is going to be destroyed! Destroyed in the Nazi Fascist hands of the DPP!' In a later exchange Zhao challenged Chen: 'I shout "long live the Republic of China," do you dare to shout "long live the Republic of China, long live the Republic of China, long live the Republic of China?"' Pundits concluded that the winners of the debate had been the NP's Chao and the DPP's Chen. In private even KMT leaders agreed that Huang Ta-chou had performed very poorly (Interview with Hsu, 2001). This was not surprising considering that Huang had been a government-appointed mayor and never stood for any elected offices before. In contrast, both Chen and Chao had been star legislators since the late 1980s. The candidates' debate performances were reflected in the actual election results, in which the DPP's Chen won, while the NP's Chao came second. 
During the late 1980s, many Taiwanese viewed limited political violence as tolerable in the light of the unfair political system. However, by the mid-1990s audience tastes had shifted, and violence appeared no longer justifiable. In fact, most opposition politicians had dropped direct action by this point. The price for DPP legislators such as Stella Chen, Huang Chao-hui and Chen San-si who still used direct action was defeat in the December 1995 Legislative Yuan elections. In the words of the Far Eastern Economic Review's Julian Baum (1995), Stella Chen 'had exhausted the patience of voters with her violent tactics in parliament.'

Taiwan's first direct presidential election in 1996 again showed what was required for politicians in terms of putting on a show and adaptability. The election pitted the KMT incumbent Lee Teng-hui against the DPP's Peng Ming-min and the NP-backed Lin Yang-kang. Both opposition campaigns were badly run and featured candidates unequipped with the necessary performance skills. Peng ignored the DPP party headquarters' call for more inclusive appeals, reverting to a style similar to that of the late 1980s and 1991, employing themes such as radical Taiwan independence and the tragedy of being Taiwanese. One Peng rally I attended in Kaohsiung in February 1996 had a funeral atmosphere, with a mix of somber music and tragic tales of Taiwanese suffering. Though such appeals may have won votes in the 1980s, they had become ineffective and even counter productive by 1996. Lin's campaign was also a disaster. Five years later, his vicepresidential running mate Hau Pei-tsun recalled of their TV ads: 'They were not professional, and they had no money and no preparations' (Interview with Hau, 2001). This was the first time Peng, Lin and Hau had stood for election, and all had communication problems. Although Peng is a fine orator in Taiwanese, he appeared uncomfortable using Mandarin. Similarly, neither Lin nor Hau were rousing speakers; in addition Hau's appeal was limited by his inability to speak Taiwanese. Moreover, after living in exile in the United States for 25 years Peng appeared out of touch with Taiwanese audience demands, as the DPP's Chen Fang-ming explained, 'He is an intellectual, he never said, "please give me your vote"' (Interview with Chen, 2001).

In contrast, President Lee Teng-hui showed how a politician could adapt. Though he had a similar government background to Lin, he had become a fiery speaker in both Taiwanese and Mandarin, and had actively campaigned for KMT candidates since 1993. In addition, Lee was far more comfortable with showmanship at rallies and in making campaign ads. In fact his election ads were well designed and gave him the image of being not only a statesmen but also approachable. One series of ads showed Lee on the world stage, shaking hands with world leaders such as Margaret Thatcher and Mikhail Gorbachev, and making a speech at Cornell University in June 1995 on his groundbreaking US visit. ${ }^{11}$ While another series showed Lee in an armchair telling how he quit smoking and how he fell in love with his wife. As in 1994, the best performer triumphed, with the incumbent Lee Teng-hui winning with over 54 per cent of the vote. 


\section{Putting on a Show in the Cable TV Era}

Changes in Taiwan's media since the mid-1990s again created a new variation in the electoral stage. The most important change has been the huge rise in cable TV and particularly the popularity of their 24-hour news channels. By 1996, 75.9 per cent of households had cable TV and this continued to rise to 85.2 per cent in 2003 (Directorate General of Telecommunications). This meant that the old organizational battle would be less effective, as increasingly TV would dominate campaigns. Parties and politicians have been forced to adjust their political theatre for the TV stage. Firstly, election rallies and speeches have to be designed to suit the tastes of their armchair audience. Secondly, politicians have to learn to debate in the politics talk shows and televised debates. Thirdly, parties and politicians have had to invest more in television campaign advertising. Lastly, the rise in TV campaigning has meant that parties must be represented by photogenic figures; therefore increasingly female and younger politicians have become the public face of parties.

By the mid-1990s, the old-style outdoor political rally had lost its novelty, and voters were no longer so attracted by serious political speeches. Politicians that still persisted with this method such as Chu Kao-cheng and Lin Chengchieh failed to be elected in both 1998 and 2001. One of the first political figures to adapt to the new media environment was the DPP's Propaganda Chief from 1995 to 1997, Chen Wen-chien. She tried to liven up the DPP's election rallies to give the party a more modern image that could attract younger voters. One of Chen's assistants even claimed that she was trying to 'Americanize' the party's campaigns (Interview with Yu, 2001). Chen designed rallies that would look good on both TV news and also for the rally audience. The most famous of these were the 'Spice Girls Campaigning Team' rallies of 1997 that combined scantily dressed dancers with lively pop music, short political speeches and the chance for the audience to directly address questions to party leaders. Of course, Chen was criticized by some party elders for trivializing politics. However, the election results, particularly in 1997 when the DPP vote share exceeded that of the KMT for the first time, ensured that even after Chen left the DPP the party continued its more youth-orientated rallies.

A new phenomenon of theatre politics since the late 1990s has been the rise of massive televised campaign rallies. In the 2000 presidential election, there was a clear contest over which party could hold the largest and most passionate rallies. Although at times the KMT was able to muster larger crowds than the DPP or independent candidate Soong Chu-yu in 2000, on close observation I found that many participants were forced to go by their work units or were being paid to attend. Soong Chu-yu's rallies in 2000 showed how well he had adapted his election rally performances. Soong is from the Mainlander ethnic community, but he has increased his nation-wide appeal by learning Taiwanese. Though not a great orator, Soong has the charisma to attract and entertain large crowds. Soong 
Chu-yu has responded to the rise in Taiwanese identity by projecting a more inclusive Taiwanese image in his performances. ${ }^{12}$ For instance, in his 2000 rallies Soong would appeal to all ethnic communities by mixing his Mandarin speeches with slogans in Hakka, Taiwanese and even Aboriginal languages. Once again, the candidates that gave the best theatre politics did the best in this campaign, with the DPP's Chen winning election with 39 per cent, closely followed by the independent Soong with 36 per cent, while the KMT's Lien Chan gained the party's record low of 23 per cent.

The 2004 presidential election was even more a battle of rallies than four years earlier. The DPP's keynote political event was a hand-in-hand human chain linking the far north with the far south of Taiwan that was attended by at least one and a half million people. This event was designed to show Taiwanese of all ethnic groups united in the face of the PRC missile threat, and was self-consciously modelled on a similar event held in the Baltic States' bid for independence from the Soviet Union in 1990. In contrast, the KMT held simultaneous anti-Chen Shui-bian rallies throughout Taiwan on 13 March under the slogan of 'Change the President, Save Taiwan' (huan zongtong, jiu Taiwan), in which up to three million people participated. The focal point involved the KMT presidential candidates and their wives kissing the ground to show the depth of their love for Taiwan. However, since both KMT candidates had more pro-China images, this was not viewed as a convincing performance. The party with the best show had won again in 2004. For although the DPP only won by a narrow margin in 2004, it had gained over 50 per cent of the national vote for the first time and seen a 10 per cent vote gain in almost every county.

Another major consequence of the rise of cable TV has been the proliferation of politics talk shows. While in the UK there are only one or two shows such as 'Question Time' per week, in Taiwan there are six or seven each night, in which politicians from the major political parties debate the issues of the day. These shows offer politicians free advertising. As DPP legislator Lai Chin-lin explained, 'They can increase your exposure and make you better known. As when you're out electioneering you can only meet a minority of constituents. If you can appear on TV, especially if it's a channel with high viewing rates, many people can see you' (Interview with Lai, 2001). However, not all politicians are able to cope with the intensity of these shows, as the performance skills required are quite different from the traditional rally speech. There is particular pressure for urbanbased politicians to regularly appear on these shows. Many of the politicians I interviewed appear on at least four such shows a week.

The rise in 24-hour cable news has also had an impact on the speeches given by political leaders. While in the past no more than a few sound bites from a speech would be shown on the TV news, since the late 1990s the cable news channels have broadcast speeches live. This has meant that a different speech is needed for each rally, also the speech must be written to appeal to both the 
rally and TV audience. Within the DPP it is felt that initially the DPP's star politician Chen Shui-bian failed to adjust to this new stage, and this damaged his 1998 mayoral re-election campaign. As the DPP's Chang Yi-shan explained, 'Before Chen Shui-bian tended to use mainly Taiwanese in his rally speeches, with much Taiwanese slang, he tried to incite the audience. However, this kind of speech came across very differently to a middle-class audience, and this gave the other side much ammunition to attack Chen Shui-bian' (Interview with Chang, 2001). Therefore, following Chen's 1998 defeat, he has used both Mandarin and Taiwanese, stopped making unscripted speeches and created a professional speech-writing team.

The final impact of the rise in cable TV channels has been the rise in importance of TV advertising in election campaigns, which in presidential elections has become the largest campaign-spending item. These were of minimal significance when they began in the early 1990s, when parties were allocated free slots on the terrestrial TV channels in proportion to how many candidates they had nominated. In 1991 the KMT was given 149 minutes of advertising time compared to 65 minutes for the DPP (Fell 2003: Table 4). The liberalization of cable channels has meant that Taiwan has adopted a system of election advertising similar to the United States, in which there is a completely free market. The degree of change is apparent from the fact that in 2000 the KMT purchased 16, 927 minutes of advertising time compared to the DPP's 9,310 (Ibid.). Therefore, making good election TV ads has become a prerequisite of a successful campaign. Just as in the United States, Taiwanese newspapers analyse and compare the quality of the previous day's slots and these are also often the subjects of everyday conversation.

The DPP was initially slow to recognize the increased significance of television advertising. Some in the party also saw this as a factor in the party's loss of the Taipei Mayoral election in 1998. That year the KMT's Ma Ying-jeou performed well in a series of candidate image ads, which showed him jogging, chatting to city residents and making tough anti-corruption speeches. As a DPP campaign manager recalled, 'In 1998 we didn't adjust to media developments, we spent too much money on newspaper ads, but ignored two new trends, the TV ads and 24-hour news channels. We had less TV ads than them and ours were of poorer quality' (Interview with Chang, 2001).

By the 2000 presidential election the DPP had improved the quality of its television advertising. This election is viewed as being a battle of TV ads, as the DPP's Yu Mei-mei commented, 'The only year that the TV ads were really effective was in 2000' (Interview with Yu, 2001). The ads showed clearly the contrasting acting abilities and judgement of audience tastes of the main candidates. The KMT spent more on TV ads than all the other four candidates put together, however, their candidate came third with only 23 per cent of the vote. Critical factors were that Lien was clearly uncomfortable about putting on a show and seriously misjudged audience tastes. In fact, a KMT ad even admitted 
Lien's lack of showmanship with the slogan 'A person that can talk can't always get things done. A person that can get things done can't always talk.' ${ }^{13}$ While Chen and Song were veteran election campaigners, this was Lien's first campaign, as he had followed a career of unelected government positions, and it showed. ${ }^{14}$ Lien clearly suffered from a lack of charisma, and when he did try to use ads to show his strength, the message was just too far from his public image to be convincing. For instance, in 2001 the KMT ran a TV ad that was a blatant copy of a Nike football boots ad, with Lien (in place of Roberto Carlos and Luis Figo) beating an assortment of monsters at football. In the 2000 presidential election, the KMT ad that was a prime example of misjudging audience tastes was known as the 'Off to War Ad' (chuzheng pian). Although this ad was a disastrous piece of theatre politics, it actually received more TV play than any other TV ad in 2000. The ad showed a group of youngsters marching and singing 'I'm off to war. I'm off to war. Because of Abian's one sentence, I'm off to war.'15 Then the narrator explains that because Chen Shui-bian said 'Long live Taiwan independence,' war may break out and 85 per cent of Taiwan's 18-35 year-olds will go to war. This ad was designed to strike fear into the hearts of Taiwanese, with the message that only the KMT could guarantee Taiwan's security. Although this kind of terror message may have worked in the past, most analysts felt the ad had backfired. While KMT supporters fearful of war switched to the most pro-China candidate Soong Chu-yu, many others saw the ad as evidence of defeatism and weakness in the face of the PRC's threats, so they switched to voting for the most pro-selfdetermination DPP. ${ }^{16}$

In contrast, both the opposition candidates Soong Chu-yu and Chen Shuibian were far more comfortable acting in TV ads. For instance, many voters were impressed with Song's ad showing him trying to help flood victims and then contrasting this with Lien's apparent indifference at the disaster zone. A flood victim is shown saying to Lien: 'Why don't you listen to us? All you can do is put on a show.' The TV ad that received the most praise from the 2000 campaign is known as the 'Kuantian Ad' (guantian pian). Narrated by Chen Shui-bian himself, the ad showed clips from Chen Shui-bian's poor hometown, his relatives and childhood neighbour and teachers, and ended with the slogan 'Because they are safe, Taiwan is safe.' Although the ad had no clear policy content, it had three symbolic messages. Firstly, it was designed to counter the KMT's terror message, to show that Chen would not take Taiwan to war. Secondly, by highlighting Chen's humble origins, viewers would be likely to contrast this with billionaire candidate, Lien Chan. Thirdly, by noting that the people of his hometown do not have foreign passports or send their money abroad, viewers would be expected to question the patriotism of the other candidates - the large number of Soong's family with US passports and property had been a much-discussed issue. Even today, when I show this ad to classes on Taiwan's electoral politics, it still has the emotional power to bring tears to the faces of many Taiwanese students. 
The audience tastes for theatre politics can change swiftly in Taiwan. In the 2001 Legislative Yuan election, the NP paid the price for not adjusting its symbolic performances. The party failed to adapt to the huge reduction of Chinese identity in Taiwan since the mid-1990s. ${ }^{17}$ It also refused to cater to the very different audiences outside Taipei, which contributed to its failure to expand its seats outside of northern Taiwan. In 2001 I spent a day as an observer at the NP's campaign headquarters in Kaohsiung, talking to campaign managers and accompanying the NP chairwoman Hsieh Chi-ta on the campaign trail. Although Hsieh was standing for election in Kaohsiung, she was clearly out of her depth in this constituency, unable to speak Taiwanese, and unfamiliar with the city. In the evening, I watched Hsieh planning a traditional Chinese nationalist rally with songs such as 'China Must Be Strong' (Zhongguo yiding qiang) and the 'Victory Song' (kaixuan ge). However, such songs have little appeal in the Taiwan-orientated southern Taiwan. Moreover, from interviewing the NP's campaigners, it was clear they showed a deep distaste for the type of performances popular with many southern voters, such as attending funerals and weddings or holding election banquets. As one NP official explained, 'DPP candidates will help their constituents when they get in trouble with the police, they will threaten the police. There is no way the NP would do this' (Interview with Chen Ming-jui, 2001). In 2001 the NP's failure to adjust their campaigning style meant that despite a record level of advertising spending, the NP was not only wiped out in Kaohsiung but in the whole of Taiwan. ${ }^{18}$

In the light of the violent post-election demonstrations in March and April 2004 numerous obituaries have been written for Taiwan's democracy. That so much of the population suspect the assassination attempt against Chen Shuibian was faked reflects the widespread cynicism with election stunts. Also of concern has been the first serious election violence for almost a decade. Just as in the 1980s the recent violent performances are aimed at winning votes from extremist voters, however, it should be recalled that once the electorate had tired of such antics the direct action politicians were defeated in 1995. It is possible that history will repeat itself.

\section{Conclusion}

This chapter has examined the relationship between Taiwanese politicians' theatre politics and their electoral fortunes. Parties and candidates have had to adjust their performances to match the changeable tastes of the electoral audience. Those that have adapted well have given themselves a greater chance of winning elections, while those that failed to adjust, such as the NP, have been punished by voters. Decisions on the form and content of the show have not solely been a top-down process. At times the parties have shown themselves to be remarkably responsive to signals from voters, by adopting radically different shows following one election defeat. Although there has been a considerable turnover of party 
politicians since the end of Martial Law, the fact that the same two parties still dominate Taiwan's political landscape 17 years later reveals the adaptability of Taiwanese parties.

It should also be remembered that the rich theatre politics of Taiwanese campaigns have numerous positive implications for its democracy. Compared to the dull campaigns and widespread voter apathy in many Western countries, Taiwan's colourful campaigns have contributed to the high levels of political interest, political participation and voting rates, even among the younger generation. ${ }^{19}$ Taking a leaf from Third-World campaigns would probably do far more to increase voting rates in the West than the recent proposals in the UK for postal, text or online voting. Moreover, such symbolic campaigns offer voters a fun and accessible form of political education. Twenty-four-hour exposure to Taiwanese politicians' countless performances on talk shows, rallies, debates and campaign advertisements, as well as showmanship in the parliaments have created a highly knowledgeable and sophisticated electorate that is able to locate parties on core issue spectrums. ${ }^{20}$

\section{References}

Baum, Julian (1995). 'All Politics is Local,' Far Eastern Economic Review, 14 December: $14-15$.

Chao, Linda and Ramon Myers (1998). The First Chinese Democracy: Political Life in the Republic of China on Taiwan (Baltimore, John Hopkins Press).

Chen, Chao-ju (1997). 'Xuanju zaoshi xiurang Taiwan jinru ganjue zhengzhi shidai' (Election Rally Shows Have Taken Taiwan into the Age of Emotional Politics), Xin xinwen (The Journalist) 545.

http://www.new7.com.tw/weekly/old/545/article082A.html (accessed 1 February 2006).

Chen, Ming-tong (1996). 'Local Factions and Elections in Taiwan's Democratization,' in Hung-mao Tien (ed.), Taiwan's Electoral Politics and Democratic Transition (Armonk, M.E. Sharpe): 174-93.

Cheng, Tun-jen and Hsu, Yung-ming (1996). 'Issue Structure, the DPP's Factionalism and Party Realignment,' in Hung-mao Tien (ed.), Taiwan's Electoral Politics and Democratic Transition (Armonk, M.E. Sharpe): 137-73. Cheng, Tzu-long (1995). Jingxuan guanggao: lilun celuo yu yanjiu anli (Campaign Advertisements: Theory, Strategy and Research Cases) (Taipei, Chungcheng).

Directorate of Telecommunications, Ministry of Transport and Communication (Taiwan) (n.d.). Cable TV Penetration Rate. Available at:

http://www.dgt.gov.tw/Chinese/About-dgt/Publication/94/images/pic-jpg/13. JPG (accessed 1 February 2006).

Esherick, Joseph and Jeffrey Wasserstrom (1990). 'Acting Out Democracy: 
Political Theatre in Modern China,' Journal of Asian Studies, 49 (4): 835-65. Fell, Dafydd (2002). 'Party Platform Change in Taiwan's 1990s Elections,' Issues and Studies, 38 (2): 31-60.

- (2003). 'Political Advertising in Taiwan: 1989-2000', Available at http:// www.nottingham.ac.uk/DafyddFellpaper1.pdf (accessed 1 Februray 2006).

Hsieh, John (2002). 'Change and Continuity in Taiwan's Electoral Politics,' in John Hsieh and David Newman (eds.), How Asia Votes (New York, Chatham House Press): 32-49.

Kaplan, John (1981). The Court Martial of Kaohsiung Defendants (Berkeley, Institute of East Asian Studies, University of California).

KMT advertisement (1994). In Lianhebao (United Daily News), 21 November: 25.

Lin, Tsong-jyi (2002). 'The Evolution of National Identity Issues in Taiwan: An Investigation of the Mass-elite Linkage,' in Stéphane Corcuff (ed.) Memories of the Future: National Identity Issues and the Search for a New Taiwan (Armonk, M.E. Sharpe): 123-43.

Rigger, Shelley (1999). Politics in Taiwan: Voting for Democracy (New York, Routledge).

Shen, Kuo-ping and Wu, Yan-ling (1996). 'Minjindang san jianke fendao yangbiao; Guomindang si gongzi jiyun zui wuchang' (The DPP's Three Musketeers Go their Separate Ways, the KMT's Four Princes' Variable Fortunes), Xin xinwen (The Journalist), 500, available at http://www.new7.com.tw/weekly/ old/500/article088.html (accessed 1 February 2006).

Tien, Hung-mao (1989). The Great Transition: Political and Social Change in the Republic of China (Taipei: SMC Publishing).

Wang, Chin-shou (1997). 'Guomindang houxuanren maipiao jiji de jianli lianzuo) (The Making and Operation of a KMT Candidate's Vote-Buying Machine), Taiwanese Political Science Review, 2: 3-62.

Wang, Peter Chen-main (1999). 'A Bastion Created, a Regime Reformed, an Economy Reengineered, 1949-1970,' in Murray Rubinstein (ed.), Taiwan: A New History (Armonk, M. E. Sharpe): 320-39.

Yang, Chia-jung (2002). 'Taiwan xuanmin zhengdang rentong chongzu de chubu tansuo: cong Guomintang de bengjie chufa' (An Exploration of Realignment in Taiwanese Voter Party Identification: Starting From the Collapse of the KMT), paper presented at the Taiwanese Political Science Conference, Chungcheng University, December 2002.

\section{Interviews}

Chang Yi-shan, Taipei, 23 October 2001. Chang worked on Chen Shui-bian's election campaigns in the 1990s. 
Chen Fang-ming, Taipei, 2 November 2001. Chen was the DPP's propaganda chief from 1992-1995.

Chen Ming-jui, Kaohsiung, 7 September 2001. Chen Ming-jui was a grassroots elected politician in the NP based in Kaohsiung.

Chu Kao-cheng, Kaohsiung, 8 October 2001. Chu was a founding member of the DPP, but later left to form the Chinese Social Democratic Party.

Hau Pei-tsun, Taipei, 7 November 2001. Hau was formerly a top ranking general. From 1990-1993 he was the Premier.

Hsu Shui-teh, Taipei, October 11, 2001. Hsu was KMT Secretary General from 1993-1996.

Lai Chin-lin, Taipei, 25 September 2001. Lai was a DPP legislator from 19982004.

Yu Mei-mei, Taipei, 27 September 2001. Yu worked in the DPP's propaganda department in the late 1990s.

\section{Notes}

1 Chinese speakers I have spoken to from the Chinese mainland and Hong Kong had not heard this phrase before and it is not in any standard Chinese dictionaries. In colloquial usage xiu can be used in isolation as the verb to "show off" or "put on a show." In addition, an adjective to describe a flashy person that loves to show off is aixiu.

2 National Day is on 10 October, and commemorates the outbreak of the rebellion that led to the founding of the Republic of China in 1911. Retrocession Day is on October 25, and commemorates the ending of Japanese rule over Taiwan in 1945.

3 The February 28 Incident refers to a Taiwanese rebellion against KMT rule in 1947 and its violent suppression, in which between ten and twenty thousand Taiwanese were killed. White Terror refers to the subsequent two decades of heavy political persecution, when tens of thousands of political prisoners were arrested.

4 After 50 years as a Japanese colony from 1895-1945, few in Taiwan could speak Mandarin Chinese. Rather than using the most widely spoken dialect in Taiwan, known as Taiwanese, the Republic of China government made Mandarin Chinese the national language. During the Martial Law era the government placed strict limits on the radio and television use of Taiwanese and at school children would be fined for speaking in Taiwanese.

5 The term Mainlander refers to those Han Chinese that came to Taiwan between 1945 and 1950 and their descendants, this group constitutes approximately 14 per cent. Native Taiwanese are those Han Chinese who already lived in Taiwan during the Japanese occupation and their descendents. They make up about 85 per cent of the population.

6 This KMT advertisement attacks the DPP's record of inciting violence, and showed a picture of a DPP campaign truck in a riot.

7 Kuo was one among hundreds of Taiwanese on a blacklist that the government banned from returning to Taiwan because of their political activities abroad. 
8 Direct elections for Taipei and Kaohsiung Mayor had been held during Martial Law, but were cancelled after 1967 and 1979 respectively. Until 1990 the president had been elected by the National Assembly, which was largely made up of members elected on Mainland China in 1947.

9 The February Incident refers to a Taiwanese uprising in the February and March 1947 and the subsequent massacre of between ten and twenty thousand Taiwanese by KMT government troops.

10 Open advocacy of Taiwan independence was seditious under Article 100 of the criminal code until 1992. The dissident Huang Hua was arrested three times and imprisoned for almost 24 years under this article.

11 Lee was the first serving Republic of China president to make an official visit to the United States, and this visit was a critical reason for the Taiwan Strait Missile Crisis of 1995-6.

12 Surveys show that respondents self-identifying as Taiwanese rose from 16 per cent in 1989 to 37.9 per cent in 2001.

13 The ad compared Lien's modesty, hard work and numerous achievements while premier, with Chen's big showmanship but lack of policy achievements while Taipei Mayor.

14 Although this was only Soong's second election campaign, he had been a key figure in election planning when he was KMT Secretary General from 1989-1993 and first appeared on a television campaign slot in 1991.

15 Abian is Chen Shui-bian's nickname.

16 KMT politicians and political scientists in my 2000 and 2001 interviews raised the idea that this ad had lost KMT voters to both opposition candidates.

17 Surveys show that respondents self-identifying as Chinese dropped from 52 per cent in 1989 to 7.9 per cent in 2001.

18 In 2001 the NP spent more on advertising than the combined total of its previous seven campaigns. The party fell from 11 seats in 1998 to only one in 2001, and this was from the small offshore island of Kinmin.

19 For instance, the voting rates for the last two presidential elections have been over 80 per cent.

20 For instance, in 2000 almost 69.7 per cent of voters could place themselves and the two main parties on the four principle issue spectrums. Data supplied by Dr Sheng Hsing-yuan from National Chengchi University's Election Study Center. 